Журнал «Герспективитаінновації наукиљ

(Серія«Гедагогіка»), Серія«ГТихологія», Серія «Медицина»

№5(5) 2021

УДК 373(492/493):37.018.43]:[616-036.21:578.834

https://doi.org/10.52058/2786-4952 -2021-5(5)-78-87

Арістова Наталія Олександрівна доктор педагогічних наук, професор, завідувач відділу міжнародних зв'язків та наукової співпраці, Інститут педагогіки НАПН України, вул. Січових Стрільців, 52-Д, м. Київ, 04503, тел. (044) 481-37-84, e-mail: n.aristova.na@gmail.com, https://orcid.org/0000-0002-0943-8039

Малихін Олександр Володимирович доктор педагогічних наук, професор, завідувач відділу дидактики, Інститут педагогіки НАПН України, вул. Січових Стрільців, 52-Д, м. Київ, 04503, тел. (044) 481-37-53, e-mail: malykhinalex1972@gmail.com, https://orcid.org/0000-0001-6042-6298

\title{
ДОСВІД ПОДОЛАННЯ НЕГАТИВНОГО ВПЛИВУ ПАНДЕМІЇ COVID-19 НА СИСТЕМУ ОСВІТИ: КРАЇНИ БЕНІЛЮКСУ
}

Анотація. У статті узагальнено досвід організації освітнього процесу в закладах освіти в країнах Бенілюксу (Бельгія, Люксембург, Нідерланди) в умовах пандемії Covid-19 на засадах здійснення порівняльного аналізу заходів, які було запроваджено в цих країнах задля мінімізації негативних наслідків екстреного (непрогнозованого) переходу до здійснення освітнього процесу в дистанційному та змішаному форматах. Досягнення мети дослідження передбачало використання методів дослідження: порівняльно-зіставного, порівняльно-типологічного та методу нетнографічного аналізу. Констатовано, що в країнах Бенілюксу (Бельгія, Люксембург, Нідерланди) достатньо оперативно й ефективно було запропоновано низку альтернативних форм організації освітнього процесу в порівнянні 3 традиційними. Визначення позитивних аспектів з досвіду подолання негативного впливу на систему освіти в країнах Бенілюксу дало змогу дійти висновку щодо доцільності імплементації цього досвіду на адаптаційній основі (за урахування специфічних особливостей організації освітнього процесу в Україні) у вітчизняну систему освіти. До таких заходів віднесено: трансляція телевізійних освітніх програм; перетворення ресурсної платформи на потужний інструмент для продовження навчання в дистанційному форматі; презентація цифрових платформ; розміщення дидактичних i методичних матеріалів на сторінках освітніх порталів; створення вебсайтів, метою яких було інформування громадян про карантинні заходи; проведення прес-конференцій, присвячених здебільшого питанням збереження здоров'я дітей шкільного віку та питанням щодо наслідків закриття закладів освіти; використання можливостей ютуб каналів офіційних інституцій системи освіти задля донесення оперативної інформації, прямо чи опосередковано пов'язаної з питаннями та відповідями про організацію освітнього процесу під час пандемії Covid-19, до керівників 
закладів освіти, учителів, учнів, батьків; відеозвернення керівників освітніх інституцій; проведення опитувань учителів і батьків задля оперативного отримання інформації щодо виявлення основних проблем, пов'язаних із дистанційним навчанням, а також максимально оперативного реагування на них.

Ключові слова: дистанційне навчання, заклади загальної середньої освіти, країни Бенілюксу, освітній процес, пандемія Covid-19, система освіти.

Aristova Nataliia Oleksandrivna Doctor of Pedagogical Sciences, Professor, Head of International Relations and Research Cooperation Department, Institute of Pedagogy of National Academy of Educational Sciences of Ukraine, Sichovykh Striltsiv St., 52-D, Kyiv, 04053, tel.: (044) 481-37-84, e-mail: n.aristova.na@gmail.com, https://orcid.org/0000-0002-0943-8039

Malykhin Oleksandr Volodymyrovych Doctor of Pedagogical Sciences, Professor, Head of Didactics Department, Institute of Pedagogy of National Academy of Educational Sciences of Ukraine, Sichovykh Striltsiv St., 52-D, Kyiv, 04053, tel.: 044) 481-37-53, e-mail: malykhinalex1972@gmail.com, https://orcid.org/0000-0001-6042-6298

\section{EXPERIENCE OF OVERCOMING THE NEGATIVE IMPACT OF THE COVID-19 PANDEMIC ON THE SYSTEM OF EDUCATION: BENELUX COUNTRIES}

Abstract. The paper summarizes the experience of organizing educational process in educational institutions in the Benelux countries (Belgium, Luxembourg, the Netherlands) amid Covid-19 pandemic on the basis of comparative analysis of measures implemented in these countries to minimize the negative consequences of emergency (unpredictable) transition of educational process in remote and blended formats. To achieve the research goal the following research methods were used: the method of comparative analysis and the method of netnographic analysis. It was stated that in the Benelux countries (Belgium, Luxembourg, the Netherlands) a number of alternative forms of organizing educational process in comparison with the traditional ones were offered rather quickly and effectively. Identification of the positive aspects of the experience of overcoming the negative impact on the education system in the Benelux countries enabled us to confirm the feasibility of implementing this experience in the domestic education system on an adaptive basis (taking into account peculiarities of educational process in Ukraine). Such measures included: broadcasting television educational programs; transforming the resource platform into a powerful tool for continuing education in the distance format; launching digital platforms; posting didactic and methodical materials on the pages of educational portals; creating websites aimed at informing citizens about quarantine measures; holding press conferences concerning the health of school-age 
children and the consequences of the closure of educational institutions; using official educational institutions' Youtube channels to convey operational information, directly or indirectly related to questions and answers about the organization of the educational process during the Covid-19 pandemic to school principals, teachers, school-age children and parents; video messaging by educational institutions heads; surveying teachers and parents in order to promptly obtain information to identify the main problems associated with distance learning, as well as the most rapid response to them.

Keywords: distance learning, general secondary schools, Benilux countries, process of education, pandemic Covid-19, system of education.

Постановка проблеми. У межах розроблення проєкту «Організація освітнього процесу в умовах непрогнозованих впливів (пандемія Covid-19): порівняльний аналіз (Україна - країни СС)» (реєстраційний номер 0121U108690), який було здійснено науковцями Інституту педагогіки НАПН України, знайшло своє відображення вивчення досвіду подолання негативного впливу пандемії Covid-19 на систему освіти країн Бенілюксу (Бельгія, Люксембург, Нідерланди). Метою проєкту було передбачено узагальнення та порівняльний аналіз зарубіжного досвіду організації освітнього процесу в умовах пандемії та його використання в системі національної освіти.

Аналіз досліджень. Вивченню особливостей організації освітнього процесу в закладах освіти України та країн СС в умовах пандемії Covid-19 присвячено наукові доробки багатьох українських учених (Н. Арістова [1; 14], М. Агарков [2], В. Бакіров [2], В. Бондаренко [3], Л. Гриневич [5], В. Кухаренко [3],Л. Ільїч [5], К. Линьов [5], О. Малихін [4; 14], Н. Морзе [5], Н. Поліхун [6], К. Постова [6], В. Прошкін [5], Г. Рій [5], І. Сліпухіна [6], О. Топузов [14], С. Уска [14], О. Шпарик [7], І. Шмелинець [5]). Разом із тим проблема подолання негативного впливу пандемії Covid-19 на системи освіти саме в країнах Бенілюксу на узагальнювальній основі не була представлена як результат окремого теоретичного дослідження.

Мета статті. Метою дослідження, здійсненого в межах виконання проєкту «Організація освітнього процесу в умовах непрогнозованих впливів (пандемія Covid-19): порівняльний аналіз (Україна - країни СC)», є узагальнення та порівняльний аналіз досвіду організації освітнього процесу в умовах пандемії Covid-19 у країнах Бенілюксу (Бельгія, Нідерланди, Люксембург). Задля досягнення поставленої мети було використано наступні методи дослідження: порівняльно-зіставний, порівняльно-типологічний та метод нетнографічного аналізу.

Виклад основного матеріалу. До країн Бенілюксу належать Бельгія, Люксембург та Нідерланди. Отже, було проаналізовано заходи, запроваджені в кожній окремій країні, задля подолання негативного впливу пандемії Covid-19 на національну систему освіти.

\section{Бельгія}


Бельгія, на території якої мешкають представники трьох мовних громад (франкомовна, фламандська та німецькомовна), поділена на три автономні регіони: Брюссельський столичний регіон, Фламандський регіон та Валлонія. Контроль за реалізацією політики Бельгії в сфері освіти й науки здійснюють мовні громади за винятком питань, пов'язаних із наданням обов'язкової освіти, виходом на пенсію працівників освіти та формулюванням мінімальних вимог щодо отримання дипломів. Після засідання Національної ради безпеки Бельгії, яке відбулося 12 березня 2020 року, Прем'єр-міністеркою Софі Вільмес було зроблено заяву про необхідність реалізації невідкладних заходів щодо запобігання поширенню коронавірусної інфекції на всій території країни. Згідно цієї заяви, заняття в традиційному (класно-урочному форматі) мали бути призупинені з 16 березня 2020 року. Отже, діти шкільного віку мали залишатися вдома. До батьків звернулися з проханням не задіювати бабусь та дідусів за наявної можливості, оскільки саме вони опинилися в групі найбільшого ризику. Також 12 березня 2020 року під час проведення засідання Національної ради безпеки було прийнято рішення, згідно якого для дітей шкільного віку, чиї батьки працювали в сфері охорони здоров'я або не мали змоги залишатися вдома, заклади освіти мали бути відкритими й надавати всебічну підтримку й допомогу в організації їхнього навчання. Цим рішенням передбачалося примусове призупинення освітнього процесу в традиційному форматі, що мало тривати до 19 квітня 2020 року 3 можливістю його подальшого подовження. Під час Великодніх канікул (5-17 квітня 2020 року) деякі школи надавали допомогу в догляді за дітьми тим батькам, які працювали в стратегічних секторах. Заклади дошкільної освіти залишалися відкритими до прийняття відповідного рішення щодо їхнього закриття.

Після закриття закладів загальної середньої освіти Національним телебаченням Бельгії було розпочато трансляцію освітніх телевізійних програм, основним меседжем яких стало підкреслення важливості продовження навчання в дистанційному форматі. Так, наприклад, Фламандське державне телебачення "VRT" почало трансляцію спеціальної освітньої програми для учнів початкової школи та підлітків. Програма транслювалася по буднях і тривала 3,5 години (з 8:30 до 10:00 - програма для учнів початкової школи; 3 10:00 до 12:00 - програма для старших учнів). Для франкомовної громади Міністерством освіти Бельгії спільно 3 державним телебаченням Франції було започатковано трансляцію телевізійної освітньої програми «Школа вдома» / "L'école à la maison" для учнів початкової школи [переклад надано в авторській редакиіï]. Ще одну освітню програму для дітей віком від 6 до 12 років «Немає занять у школі, готуємося до іспитів» / "Y'a pas école, on revise!" [переклад надано в авторській редакиї] було розроблено й запроваджено Міністерством освіти Бельгії спільно 3 франкомовним бельгійським радіо і телебаченням “RTBF”. Головна мета освітньої програми надання додаткової допомоги дітям у вивченні таких предметів, як: «Математика», «Французька мова», «Наука» тощо. Задля надання допомоги 
Журнал«Герспективитаінновації наукиљ

(Серія «Гедагогіка», Серія «Гиихологія»), Серія«Медицина»

№5(5) 2021

батькам і дітям різні регіональні телевізійні канали також транслювали відеоуроки з різних навчальних предметів [8; 10; 11].

Після закриття закладів освіти через упровадження карантинних заходів ресурсна платформа "KlasCement", яку було створено в 1998 році, стала потужним інструментом для продовження навчання в дистанційному форматі. В умовах пандемії Covid-19 ресурсна платформа діяла за підтримки Міністерства освіти Бельгії, а іiї змістовий контент постійно оновлювався. Призупинення навчання в традиційному (класно-урочному) форматі на платформі спонукало до розміщення тематичних сторінок (із використанням можливостей платформи) 3 рекомендаціями і практичними порадами для вчителів щодо організації навчання в дистанційному форматі в закладах освіти різних рівнів, а також навчальних матеріалів для учнів 3 різних шкільних предметів [11].

Франкомовною громадою Бельгії було спрезентовано цифрову платформу "E-classe", розроблену спільно 3 франкомовним бельгійським радіо і телебаченням "RTBF/Sonuma”. До беззаперечних переваг цифрової платформи слід віднести наявність значної кількості освітніх матеріалів для дітей шкільного віку, корисних порад для вчителів щодо застосування методів дистанційного навчання, рекомендацій, навчальних посібників, аудіо- i відеоресурсів тощо [11].

18 березня 2020 року Фламандським Міністерством освіти і професійної підготовки було організовано й проведено сеанс прямої трансляції для вчителів (у соціальній мережі «Фейсбук»), присвячений запровадженню альтернативних форм організації освітнього процесу. Учителям і викладачам також надавали різнопланову методичну допомогу щодо організації освітнього процесу в дистанційному форматі. Так, значну кількість методичних і дидактичних матеріалів було розміщено на сторінках освітнього порталу Федерації Валлонія-Брюссель "Enseignement.be" (www.enseignement.be/index.php). Вичерпну інформацію стосовно надання освітніх послуг i застосування цифрових інструментів в освітньому процесі під час пандемії Covid-19 також можна було знайти на спеціальному сайті "Coronavirus" https://onderwijs.vlaanderen.be/nl (для керівників закладів освіти, учителів, учнів i батьків), створеному Фламандським міністерством освіти та професійної підготовки.

\section{Люксембург}

Як і в багатьох інших країнах світу всі сфери суспільного життя (у тому числі й сфера освіти) у Люксембурзі зазнали певних негативних наслідків через спалах коронавірусної інфекції (Covid-19). Так, задля зниження ризику зараження вірусом 316 березня 2020 року традиційне навчання за класноурочною формою було тимчасово призупинено. А після ухвалення парламентом Люксембургу Закону «Про врегулювання виняткової ситуації 3 пандемією Covid-19» від 18 березня 2020 року, спрямованого на обмеження пересування громадян, освітній процес у закладах освіти було переведено в 
дистанційний формат. Урядом Люксембургу створено вебсайт «Coronavirus», мета якого - своєчасне інформування громадян про карантинні заходи тощо $[9 ; 11]$.

У 2020 році Службою преси і комунікації Міністерства освіти, дітей і молоді Люксембургу було організовано проведення 23-х прес-конференцій, 14 із яких було присвячено питанням збереження здоров'я дітей шкільного віку та питанням, пов'язаним із наслідками закриття закладів освіти. Також протягом 2020 року Службою преси і комунікації Міністерства освіти було підготовлено значну кількість буклетів, листівок і наочних матеріалів задля забезпечення процесу оперативного інформування керівників закладів освіти, учителів, учнів i батьків про коронавірусну інфекцію, запобігання ії розповсюдження тощо.

Міністерством освіти, дітей i молоді Люксембургу було розроблено освітній вебсайт «Школа вдома» / "Schoul Doheem" https://schouldoheem.lu/lu [переклад надано в авторській редакиії], на якому надавали корисну інформацію для вчителів і батьків; навчальні матеріали для учнів; новини, практичні поради для вчителів щодо організації освітнього процесу в дистанційному форматі, посилання на різноманітні освітні ресурси.

Цікавим фактом виявилося те, що в 2020 році на офіційну сторінку Міністерства освіти, дітей і молоді Люксембурга в соціальній мережі «Фейсбук» підписалося більше 10000 людей. Оголошення про закриття закладів освіти від 12 березня 2020 року та продовження призупинення діяльності закладів освіти від 18 березня 2020 року, які було розміщено на офіційній сторінці Міністерства освіти, дітей і молоді Люксембурга в соціальній мережі «Фейсбук», викликали неабиякий інтерес серед іiі користувачів.

Протягом 2020 року на ютуб каналі Міністерства освіти, дітей і молоді Люксембурга було розміщено 35 відеороликів, призначених для керівників закладів освіти, учителів, учнів і батьків (у тому числі 16 про запобігання поширенню коронавірусної інфекції; 4 відеоролики для дітей про коронавірусну інфекцію; 1 відеоролик із записом прямого етеру 3 Міністерством освіти, дітей і молоді Люксембурга: питання та відповіді про організацію освітнього процесу під час пандемії Covid-19). Також велику кількість переглядів і значний інтерес мали відеозвернення Міністра освіти, дітей і молоді Люксембурга Клода Мейша до учнів початкової школи від 17 березня 2020 року та відеозвернення «Другий тиждень вдома» від 24 березня 2020 року.

На сторінці офіційного сайту Міністерство освіти, дітей і молоді Люксембурга «Питання та відповіді: Заходи, пов'язані з Covid-19 у школах і дитячих установах» розміщено відповіді на поширені питання про коронавірус (https://men.public.lu/en/support/coronavirus/faq-en.html). Відповіді надано люксембурзькою, англійською, французькою, німецькою й португальською мовами. 
Через 15 днів після призупинення навчання в закладах загальної середньої освіти за традиційною (класно-урочною) формою Міністерство освіти, дітей і молоді Люксембурга розпочало опитування вчителів і батьків задля отримання інформації щодо виявлення основних проблем, пов'язаних із дистанційним навчанням. Результати, отримані під час опитування, показали, що більшість учителів і батьків легко адаптувалися до дистанційного навчання. Проведене опитування надало змогу також зібрати понад 7000 зауважень і пропозицій щодо покращення організації освітнього процесу в дистанційному форматі. Було 3'ясовано, що основною проблемою, з якою стикнулися діти шкільного віку та студентська молодь, була відсутність доступу до швидкісного інтернету та необхідного сучасного комп'ютерного обладнання (смартфони, планшети, ноутбуки) [11].

\section{Нідерланди}

Трохи інша ситуація відбувалася в Нідерландах. Так, 12 березня 2020 року на офіційному вебсайті уряду Нідерландів було розміщено інформацію щодо запобігання поширенню коронавірусу (Covid-19) на території країни й пропозиції щодо переведення лекцій у закладах вищої та вищої професійної освіти в дистанційний формат відповідно до рекомендацій Національного інституту охорони здоров'я та навколишнього середовища. Закладам дошкільної, загальної середньої та професійної освіти було дозволено залишатися відкритими через думку про те, що діти дошкільного та шкільного віку не належать до груп високого ризику. Проте, незважаючи на рекомендації деякі університети повністю перейшли на дистанційну форму навчання ще до прийняття офіційного рішення про закриття закладів освіти та переведення традиційного (класно-урочного) навчання в дистанційний формат, яке було ухвалено 15 березня 2020 року урядом Нідерландів. Передбачалося, що карантинні заходи будуть тривати до 28 квітня 2020 року, а заклади загальної середньої освіти будуть працювати в дистанційному форматі до 3 травня 2020 року. Проте, навіть і після зазначеного терміну не всі заклади загальної середньої освіти відновили навчання в традиційному форматі $[11 ; 12 ; 13]$.

Відразу після закриття шкіл представники закладів початкової та загальної середньої освіти, дитячих центрів спрямували зусилля на надання додаткової допомоги дітям, які належать до вразливих верств населення, а також дітям, для яких нідерландська мова не $\epsilon$ рідною. Батьки цих дітей постійно отримували практичні поради щодо організації читання в домашніх умовах, збереження здоров'я. Особливу увагу приділяли дітям, котрі знаходилися в центрах тимчасового розміщення біженців.

Дещо інша ситуація склалася $з$ дітьми старшого шкільного віку. Так, після закриття шкіл учителі почали проводити уроки в дистанційному форматі. Зважаючи на те, що заклади загальної середньої освіти та вищої освіти вирізняються високим ступенем автономності, прийняття всіх рішень щодо відбору навчального матеріалу та освітніх ресурсів, необхідних в організації освітнього процесу в дистанційному форматі, було покладено на керівництво 
закладів освіти.

Громадською організацією 3 питань освіти "Kennisnet" спільно 3 Міністерством освіти, культури і науки та іншими організаціями було розроблено освітній вебсайт "Lesopafstand" https://www.lesopafstand.nl, спрямований на надання учням і вчителям закладів загальної середньої та професійно-технічної освіти інформації, необхідної для ефективної організації дистанційного та/або гібридного навчання. На сторінках цього вебсайту було розміщено інструкції щодо організації освітнього процесу в дистанційному форматі, відеоуроки з різних предметів, навчальні матеріали в цифровому форматі тощо[13].

Учителі початкових класів, закладів загальної середньої та професійнотехнічної освіти також мали змогу скористатися методичними матеріалами та практичними порадами, розміщеними на сторінках вебсайту "Leraar24.nl" https://www.leraar24.nl.

У великих містах (Амстердам, Роттердам та ін.) тисячі дітей 3 неблагополучних сімей отримали допомогу у вигляді планшетів та ноутбуків, $\mathrm{i}$ майже всі школи були відкритими для дітей, чиї батьки не мали змогу організувати їм належний догляд в домашніх умовах [13].

Висновки. Отже, у країнах Бенілюксу (Бельгія, Люксембург, Нідерланди) достатньо оперативно й ефективно було запропоновано низку альтернативних форм організації освітнього процесу в порівнянні з традиційними. Визначення позитивних аспектів з досвіду подолання негативного впливу на систему освіти в країнах Бенілюксу дало змогу дійти висновку щодо доцільності імплементації цього досвіду на адаптаційній основі (за урахування специфічних особливостей організації освітнього процесу в Україні) у вітчизняну систему освіти. Досягнення мети дослідження передбачало використання методів дослідження: порівняльно-зіставного, порівняльнотипологічного та методу нетнографічного аналізу. До таких заходів віднесено: трансляція телевізійних освітніх програм, перетворення ресурсної платформи на потужний інструмент для продовження навчання в дистанційному форматі; презентація цифрових платформ; розміщення дидактичних $\mathrm{i}$ методичних матеріалів на сторінках освітніх порталів; створення вебсайтів, метою яких було інформування громадян про карантинні заходи; проведення пресконференцій, присвячених здебільшого питанням збереженням здоров’я дітей шкільного віку та питанням щодо наслідків закриття закладів освіти; використання можливостей ютуб каналів офіційних інституцій системи освіти задля донесення оперативної інформації, прямо чи опосередковано пов'язаної з питаннями та відповідями про організацію освітнього процесу під час пандемії Covid-19, до керівників закладів освіти, учителів, учнів, батьків; відеозвернення керівників освітніх інституцій, проведення опитувань учителів і батьків задля оперативного отримання інформації щодо виявлення основних проблем, пов'язаних із дистанційним навчанням, а також максимально оперативного реагування на них. 


\section{Jimepamypa:}

1. Арістова Н. О. Дистанційне навчання в сучасних умовах: ставлення студентів в Україні та Латвії / Н.О. Арістова // Матеріали V Міжнародної науково-практичної конференції «Педагогічна компаративістика і міжнародна освіта 2021: інновації в освіті в контексті європеїзації та глобалізації» (27-28 травня 2021 року). - Тернопіль : Крок, 2021. - С. 54-55.

2. Бакіров В., Агарков М. Пандемія може на завжди змінити вищу освіту. Дзеркало тижня: вебсайт. URL: https://zn.ua/ukr/EDUCATION/pandemija-mozhe-nazavzhdi-zminiti-vishchuosvitu.html (дата звернення: 10.11.2021).

3. Екстрене дистанційне навчання в Україні : монографія / за ред. В. М. Кухаренка, В. В. Бондаренка. - Харків : Вид-во КП «Міська друкарня», 2020. - 409 с.

4. Малихін О. В. Сучасний досвід організації дистанційного навчання у вищій школі: Україна-Латвія / О.В.Малихін // Матеріали V Міжнародної науково-практичної конференції «Педагогічна компаративістика і міжнародна освіта 2021: інновації в освіті в контексті європеїзації та глобалізації» (27-28 травня 2021 року). - Тернопіль : Крок, 2021. - С. 63-64.

5. Організація освітнього процесу в школах України в умовах карантину: аналітична записка; Л. Гриневич, Л. Ільїч, Н. Морзе, В. Прошкін, І. Шемелинець, К. Линьов, Г. Рій. Київ : Київський університет імені Бориса Грінченка, 2020. - 76 с.

6. Поліхун Н. І. Виклики дистанційного навчання. / Поліхун Н. І., Постова К. Г., Сліпухіна I. А. // Освіта та розвиток обдарованої особистості. - 2020. - № 3 (78). -С. 63-69.

7. Шпарик О. М. Освітній процес в Україні та країнах ЄС в умовах дистанційного та змішаного форматів: теоретичний аспект / O. М. Шпарик // Матеріали VI Міжнародної науково-практичної конференції «Інформаційні технології в культурі, мистецтві, освіті, науці, економіці та бізнесі» (22-23 квітня 2021 року). - Київ, 2021. - С. 449-451.

8. Belgian French Community: Support to primary and secondary school teachers put in place during the COVID pandemic. Eurydice: website. URL: https://eacea.ec.europa.eu/nationalpolicies/eurydice/content/belgian-french-community-support-primary-and-secondary-school-teachersput-place-during_en (дата звернення: 19.10.2021).

9. Coronavirus. The Luxembourg Government: website. URL: https://covid19.public.lu/ en.html (дата звернення: 14.11.2021).

10. Johnston J. Coronavirus: Belgium cancels school classes, closes bars. The Brussels Time. URL: https://www.brusselstimes.com/news/art-culture/100094/coronavirus-belgium-cancels-schoolclasses-closes-bars/ (дата звернення: 10.10.2021).

11. National learning platforms and tools. UNESCO: website. URL: https://en.unesco.org/covid19/educationresponse/nationalresponses (дата звернення: 17.09.2021).

12. New measures to stop spread of coronavirus in the Netherlands. Government of the Netherlands: website. URL: https://www.government.n1/latest/news/2020/03/12/new-measures-tostop-spread-of-coronavirus-in-the-netherlands (дата звернення: 05.09.2021).

13. The Netherlands Covid-19 education response. Multinclude: website. URL: https://multinclude.eu/ 2020/05/27/the-netherlands-covid-19-education-response/ (дата звернення: 23.09.2021).

14. Topuzov, O., Malykhin, O., Usca, S., \& Aristova, N. (2021). Ukrainian-Latvian comparative studies on university education: Common European values and current challenges. Society. Integration. Education: Proceedings of the International Scientific Conference, I, 696-706. DOI: doi.org/10.17770/SIE2021VOL1.6423.

\section{References:}

1. Aristova, N. O. (2021). Dystantsiyne navchannya v suchasnykh umovakh: stavlennya studentiv v Ukrayini ta Latviyi [Distance learning in present-day conditions: attitudes of students in Ukraine and Latvia] : Proceedings of the $V$ Mizhnaroyi naukovo-praktychnoyi konferentsiyi «Pedagogichna komparatyvistyka i mizhnarodna osvita 2021: innovatsyi $v$ osviti $v$ konteksti 
yevropeyizatsyi ta globalizatsiyi. - The Fifth International Scientific and Practical Conference "Pedagogical comparative studies and international education 2021: innovations in education in the context of Europeanization and globalization». (pp. 54-55). Ternopil: Krok [in Ukrainian].

2. Bakirov, V. \& Agarkov, M. Pandemiya mozhe na zavzhdy zminyty vyshchu osvitu [Pandemic can change higher education forever]. Dzerkalo tyzhnya: website. URL: https://zn.ua/ukr/EDUCATION/pandemija-mozhe-nazavzhdi-zminiti-vishchu-osvitu.html (data zvernennya: 10.11.2021) [in Ukrainian].

3. Kukharenko, V. M. \& Bondarenko V. V. (Eds). (2020). Ekstrene dystantsiyne navchannya v Ukrayini [Extreme distance learning in Ukraine]. Kharkiv : Vy`d-vo KP «Mis`ka drukarnya» [in Ukrainian].

4. Malykhin, O. V. Suchasnyi dosvid organizatsiyi dystantsiyinogo navchannya u vyshhyi shkoli: Ukrayina-Latviya [Present-day experience of organizing distance learning in higher school]: Proceedings of the V Mizhnaroyi naukovo-praktychnoyi konferentsiyi «Pedagogichna komparatyvistyka i mizhnarodna osvita 2021: innovatsyi $v$ osviti $v$ konteksti yevropeyizatsyi ta globalizatsiyi. - The Fifth International Scientific and Practical Conference "Pedagogical comparative studies and international education 2021: innovations in education in the context of Europeanization and globalization». (pp. 63-64). Ternopil: Krok [in Ukrainian].

5. Grynevych, L., Ilyich, L., Morze, N., Proshkin, V., Shemelynecz, I., Lynov, K., \& et al. (2020). Organizatsiya osvitnogo procesu v shkolakh Ukrayiny v umovakh karantynu: analitychna zapyska [Organization of educational process in schools of Ukraine amid quarantine: analytical note]. Kyiv : Kyyivskyi universytet imeni Borysa Grinchenka [in Ukrainian].

6. Polikhun, N. I., Postova, K. G., \& Slipukhina, I. A. (2020). Vyklyky dystantsiynogo navchannya [Challenges of distance learning]. Osvita ta rozvytok obdarovanoyi osobystosti. Education and development of gifted personality, 3 (78), 63-69 [in Ukrainian].

7. Shparyk, O. M. (2021). Osvitnii protses v Ukrayini ta krayinakh YeS v umovakh dystantsiyinogo ta zmishanogo formativ: teoretychnyi aspekt [Educational process in Ukraine and EU countries amid distance and blended learning formats: theoretical aspect]. Proceedings of the VI Mizhnarodnoyi naukovo-praktychnoyi konferentsiyi «Informatsiyini tekhnologiyi $v$ kulturi, mystetstvi, osviti, nautsi, ekonomitsi ta biznesi» - The Sixth International Scientific and Practical Conference "Information technologies in culture, art, education, science, economy and business» (pp. 449-451 ). Kyiv [in Ukrainian].

8. Belgian French Community: Support to primary and secondary school teachers put in place during the COVID pandemic. Eurydice: website. URL: https://eacea.ec.europa.eu/nationalpolicies/eurydice/content/belgian-french-community-support-primary-and-secondary-schoolteachers-put-place-during_en (data zvernennya: 19.10.2021).

9. Coronavirus. The Luxembourg Government: website. URL: https://covid19.public.lu/ en.html (data zvernennya: 14.11.2021).

10. Johnston J. Coronavirus: Belgium cancels school classes, closes bars. The Brussels Time. URL: $\quad$ https://www.brusselstimes.com/news/art-culture/100094/coronavirus-belgium-cancels-schoolclasses-closes-bars/ (data zvernennya: 10.10.2021).

11. National learning platforms and tools. UNESCO: website. URL: https://en.unesco.org/covid19/educationresponse/nationalresponses (data zvernennya: 17.09.2021).

12. New measures to stop spread of coronavirus in the Netherlands. Government of the Netherlands: website. URL: https://www.government.nl/latest/news/2020/03/12/new-measures-tostop-spread-of-coronavirus-in-the-netherlands (data zvernennya: 05.09.2021).

13. The Netherlands Covid-19 education response. Multinclude: website. URL: https://multinclude.eu/2020/05/27/the-netherlands-covid-19-education-response/ (data zvernennya: 23.09.2021).

14. Topuzov, O., Malykhin, O., Usca, S., \& Aristova, N. (2021). Ukrainian-Latvian comparative studies on university education: Common European values and current challenges. Society. Integration. Education: Proceedings of the International Scientific Conference, I, 696-706. DOI: doi.org/10.17770/SIE2021VOL1.6423. 